\title{
The Prevent paradox: destroying liberalism in order to protect it
}

\section{Christos Boukalas ${ }^{1}$ (D)}

Published online: 18 March 2019

(C) The Author(s) 2019

\begin{abstract}
Counter-extremism is the most dynamic part of UK counterterrorism policy. This article examines Prevent, the flagship counter-extremism programme, through a statetheoretical lens. It addresses questions of state institutionality, state power, and statesociety relations. It argues that counter-extremism aims to avert the possibility of a political future by repressing the formation of non-liberal political subjectivities. To achieve this, Prevent divides society along political lines; aligns welfare institutions with the security apparatus; mobilises society in a security endeavour; exercises an authoritarian 'pastoral' power; replaces trust with generalised suspicion; and construes subjectivities without capacity for historical agency. Therefore, Prevent is a political paradox: an anti-liberal project aiming to secure and perpetuate liberalism.
\end{abstract}

\section{Introduction: From community to society (and from society to the state)}

Since its strategic relaunch in 2011, counter-extremism has been the most dynamic part of UK counterterrorism policy. It is prominent in public discourse, in institutional and strategic development, and it expands the boundaries of where security policy can apply and what it can achieve. This article examines the institutional structure, function, and rationale of Prevent, Britain's flagship counter-extremism programme; and appreciates them in the light of political and state theory. In doing so, it offers a novel approach to counter-extremism, a wider vista - and deeper critique - thereof.

Critical accounts of Prevent tend to conceptualise it as a relation between the state and British Muslim communities. They find Prevent is 'construing the Muslim community as the actionable site of counterterrorism' ([82]: 7). They theorise it as a an intervention in state-community and inter-community relations [84]; as a project that maps the Muslim community [3]; coercively intervenes in the realm of theology [54];

Christos Boukalas

christos.boukalas@northumbria.ac.uk

1 Northumbria Law School, Northumbria University, Law Building, City Campus East, Newcastle upon Tyne NE1 8ST, UK 
introduces a clash of values that alienates Muslim youths and renders them subject to surveillance [17, 69, 82, 85]; and polices multiculturalism by construing the 'Muslim' as a suspect category and by entangling British Muslims in its promotion and its resistance [71]. ${ }^{1}$ These accounts offer powerful expositions of the persistently discriminatory, stigmatising and alienating effects of Prevent, and important insights into the fabrication of suspect categories. They run, however, the danger of representing counter-extremism (and counterterrorism more broadly) as a closed-circuit relation between the state and a specific community, which leaves the rest of society unaffected. If Prevent construes 'the Muslim community as the actionable site of counterterrorism', its critique does the same, vanishing 'the rest' of society from the analysis and therefore missing the serious implications of counter-extremism for it.

More recently, a new wave of critique has emerged. Reacting to the imposition of a statutory duty on public sector institutions to participate in Prevent, it shifts analytical attention from the 'targets' to the 'agents' of counter-extremism. While still viewing Prevent as a state-vs-Muslim relation, it addresses the ways in which it implicates broader sections of society. It especially highlights the colonisation of social policy by the logic of security, and the disruption of welfare institutions' institutional autonomy and the professional ethos of their personnel [33, 64, 72, 73]. Finally, rare accounts engage with Prevent as a project concerning the whole of society, one that inscribes it into a total net of surveillance [32], and seeks to uproot the potential for social emancipation [81].

It is this 'second wave' of counter-extremism critique that this article draws from, and in which is hopes to contribute. The article sees counter-extremism as a strategy that concerns society as a whole, and deciphers some of its key modalities and implications. To do so, its analytical focus falls on the state. Discussing society through a lens turned on the state is made possible by adopting a strategic-relational approach. This views the state as neither a thing (a value-free institutional assemblage), nor a subject (with innate will, interests, and power) separate from society. On the contrary, it views the state as a social relation, an institutional effect of social dynamics, that can, and does, exercise strategic agency within society $[10,51,52,68]$. If the state is 'the official résumé of society' ([57]: 156), focusing on the state can illuminate the implications of counter-extremism for society.

The heuristic of a strategic-relational approach can expand the understanding, and critique, of counter-extremism. In placing the analytical focus on the state, it addresses the forgotten partner of counter-extremism, which is largely taken for granted or overlooked by analysts. This blind-spot is baffling, considering that counter-extremism is a state strategy, and a novel one at that. It raises direct, thus far un-asked, questions regarding what kind of state designs and implements such a strategy; and how does such a strategy affect the institutionality and powers of the state. Crucially, counterextremism is a state strategy that engages society, both as its target and as its agent. This raises questions for state-society relations, particularly regarding the modalities of state power and the political subjectivities counter-extremism implies. Moreover, in being strategic, counter-extremism is temporarily prospective. Its results apply on the future. It affects not only the present of society, but its reproduction into the future. Finally, the focus on the state invites the question of politics. Counter-extremism is a political

\footnotetext{
${ }^{1}$ For a fuller account of this approach: [71]: 725-730.
} 
strategy: the relations it implicates (state institutionality, state power, state-society) pertain to the institution, organisation, and direction of society - they are deeply political ([10]: 11-13); and so are its conceptual premises, targeting, and objectives.

These are the perspectives this article seeks to open. Its first substantive section provides a brief account of the development of Prevent, showing its increasing strategic importance for the state. The second section outlines Prevent's rationale, which demarcates counter-extremism as a terrain of ideological combat between liberalism and non-liberal worldviews. The third section describes the institutional architecture of Prevent, to argue that it constitutes an alignment of state institutions in an endeavour directed by the security apparatus. The fourth section examines how Prevent mobilises society in an hegemonic project. It claims that the involvement of welfare professionals in a security endeavour is made possible by the representation of Prevent as a therapeutic programme, rather than a coercive one. The fifth section deciphers the type of power Prevent exercises, and the subjectivities it implies. It argues that Prevent points to a pre-modern pastoral power; recasts social relations as relations of security; and calls forth a suspicious citizen. The article concludes by highlighting the paradox of Prevent: in order to secure liberalism, it promotes a political constellation of power, society, and subjectivity that is deeply anti-liberal.

\section{Counter-extremism strategy}

Counter-extremism is a strategy through which the state seeks to counter the threat of extremism. This self-evident statement appears innocuous, until we consider that this is the first time in its history that the British state conceptualises extremism as a threat. In its novelty, the strategy implicates the strategist. Accordingly, the article will grapple with the implications of counter-extremism for the state and for its relations to society. But first, a brief account of the historic development of counter-extremism will outline some basic contours of the strategy and testify to its importance for the state.

Prevent is one of the four pillars of Contest, the UK domestic counterterrorism strategy, along with Protect, Prepare and Pursue. Of the four, Protect and Prepare are reactive and resilience-building; they seek to fortify infrastructure against terrorist attacks and mitigate their impact. Pursue and Prevent are preventive. The former is intelligence-led and seeks to detect and disrupt threats 'at the earliest possible stage by any means necessary' ([35]: 10). Prevent intervenes even earlier, aiming 'to stop people becoming terrorists or supporting terrorism and extremism' ([41]: 3; [45]: 9). Pursue and Prevent are unified in a continuum that seamlessly links banal Prevent interventions with surveillance by the intelligence agencies ([38]: 29).

In 2011 Prevent underwent strategic reconfiguration. It dropped its initial integration and cohesion mission, to focus exclusively on counter-extremism ([75]: 146-147). It also broadened its scope, to apply beyond 'violent extremism' as was hitherto the case, to the non-violent variety too. And, it expanded its targeting priorities to include farright ideologies along with jihadism (HMG 2011: 12, 59, 62, 65). In 2013, the Prime Minister announced the creation of the Extremism Task Force, a cabinet-level body that brings the overall strategic design of counter-extremism directly under the PM.

To date, the latest major development of the strategy came in the form of the 2015 Counterterrorism and Security Act (CtSA). The Act creates a statutory duty 'to prevent 
people from being drawn into terrorism' and imposes it on all local government authorities; penitentiary institutions; police forces; Port, Border and Nuclear agencies; public health trusts and councils; and the entire education and childcare sector (Sch.6). CtSA authorises the Home Secretary to amend or add to this list at her discretion (s.27). It also authorises the Secretary to specify how the authorities should fulfil their duty, by issuing guidelines and mandatory orders (s.29-30). Finally, it sets out a structure through which, under guidance and monitoring by the Home Secretary, each local authority assesses and supports individuals in danger to be drawn into terrorism (s.3637). As the content of the duty is not defined in law but left to be determined by the Secretary, the institutions upon which it is imposed and their personnel come, partially, under Home Office control. There are unfulfilled but persistent plans to expand and strengthen the statutory footing of counter-extremism. They would include Extremism Disruption and Closure Orders, issued by the Home Secretary on police or intelligence advice; a legal duty to terminate the employment of public sector personnel with extremist background; and criminal sanctions for unrepentant extremists ([6]: 868). There are also ongoing efforts to force internet service providers to monitor and disrupt extremist expression online [58].

This brief history outlines the rise of counter-extremism from a confused, backwater policy, to a defined, high-priority, political strategy. To pursue the strategy, the state needs to define its object. Again, it is the first time that the British state defines 'extremism'. The following section outlines the lexicon of Prevent and the rationale that informs it.

\section{Rationale (and glossary): An ideological battleground}

Prevent is a national security programme. It represents an 'unyielding fight against extremism' (May in [42]: 2). Its overall mission is 'to stop people becoming terrorists or supporting terrorism and extremism' ([41]: 3; [45-47]: 9).

The process through which someone comes to support extremism is radicalisation. It is seen as the root cause of terrorism, and Prevent is designed to disrupt and reverse it ([42]: 108). Prevent is concerned with those who promote ideologies that could justify terrorist acts, and those who are susceptible ('vulnerable') to them. Likely to be involved in radicalisation are the young, those of lower socio-economic position, and those who distrust Parliament, believe that ethnic and religious groups should not mix, have negative views of the police, or perceive themselves in conflict with British cultural identity ([42]: 17-18).

Extremism is both the outcome and the source of radicalisation. It is 'the foundation' of terrorism ([42]: 3). It is defined as 'the vocal or active opposition to British values' ([42]: 107). These include 'democracy, the rule of law, equality of opportunity, freedom of speech, and the rights of all men and women to live free from persecution of any kind' ([42]: 34, 44). Thus, 'British values' comprise the core values of political liberalism.

Prevent is concerned with extremism even when espoused by 'apparently' nonviolent and lawful groups, for they 'create an environment in which people can be drawn in terrorism' ([35]: 12, 62, 59) and cause 'many other harms' in justifying violence, rejecting the democratic system, damaging community relations, and undermining shared values ([37]: 10-13; [83]: 3; [45]: 17). Among the various types 
of extremism, Prevent prioritises its targets according to the active threat they pose to national security ([35]: 10, 62; [37]: 21-23; [42]: 3, 5, 25). Thus conceived, Prevent has three main objectives.

The first is challenging the ideology that supports terrorism and those who promote it. It involves constructing and promoting counter-narratives based on British values; and ensuring that extremists cannot 'peddle their messages' without rebuttal or prosecution. The second objective is protecting vulnerable people. Prevent strives to identify those vulnerable to radicalisation, and stop or reverse that process. Its Channel structure promotes 'de-radicalisation': a process of cognitive and behavioural change, involving adjustment of ideas and worldviews, and severance of links with radicalisers. The third objective is supporting sectors and institutions where there are risks of radicalisation, i.e. schools, universities, prisons, mosques, the internet, the health service, etc. These sectors are settings where radicalisation can occur, but also challenged ([35]: 44-64).

The rationale of Prevent is premised on two assumptions. The first is that terrorism results from extremism. Prevent equates the two ([45]: 9) and targets extremism as an existential threat per se (Cameron in [37]: 5). The second is that the process of radicalisation is reversible. Accordingly, Prevent targets the potentiality of becoming extremist. It is therefore a pre-emptive project: it seeks to neutralise the threat of terrorism not only before it materialises, but before it is formed by denying it the conditions for its formation ([53]: 307; [56]: 90).

A third, tacit, premise is that radicalisation is the sole reason for terrorism ([34]: 7), attributed to personal psychopathology ([22, 56]: 193-194). Thus, Prevent designates certain ideas and worldviews as pathological and denies them rational, affective, or material basis. It targets their formation and circulation. The ideas in question are those that contravene British values. There is a tension here: On the one hand, this is the first time that the British state undertakes the programmatic construction of British values and their imposition on society ([11]: 90). In contrast to republican political systems, British national values and forms of citizenship were developed in an individualistliberal context, at a distance from the state [26]. On the other hand, the state is a key agency in construing the nation. While it claims to only express an already-existing 'national culture', it largely defines national culture and organises it into particular political projects ([23]: 260; [68]: 93-120). This is a first paradox of Prevent: in defining national values, the state breaches one of the values it had hitherto help to instil: that of the supposedly organic and a-political character of national values.

'British values' are the pillars of political liberalism. This political determination of the national designates another shift in the definition of nationhood. It brings Britain in proximity to the United States, the state that par excellence defines nationhood exclusively on political terms, like loyalty to the flag, the Constitution, representative democracy, etc. ([52]: 154-155). Thus, the non-liberal becomes un-British: the political antagonist is expelled from the nation. In this manner, Prevent designates a field of ideological combat between two irreconcilable subjects: the liberal British citizen, and the anti-liberal, un-British extremist. In this combat, British/liberal values are both the object of protection and the decisive weapon ([56]: 195-196).

The terrain of this combat, and locus of Prevent intervention, is the process of idea formation. Prevent focuses not only on the transmitter of dangerous political ideas but also on their audience, those 'vulnerable' to extremist messages. In surprising affinity to the medieval 'persecuting state', the soul becomes the terrain in which security 
conflicts are played out ([62]: 84). Prevent inspects the most intimate relation between the individual and her mind. This is a definite sign of a police state ([7]: 233).

Crucially, the aim of the effort is the pre-emptive elimination of the radical, the nonliberal. In preventing the formation of non-liberal subjectivities, counter-extremism aims to cancel the potentiality of a political future and freeze society into an eternal liberal present. Counter-extremism aims to end social change. It declares that the social order is perfected, that history has ended. To achieve this monumental goal, the state assembles a particular mechanism, outlined in the following section.

\section{Structure and functions: State project, statist governance}

Prevent comprises a peculiar, overlooked by analysts, mechanism. The strategic design and evaluation of counter-extremism policy is made at cabinet level by the Extremism Task Force, which comprises ministers and Police and Intelligence chiefs directly under the PM [70]. Operationally in charge of Prevent is the Home Secretary ([35]: 109-111; [42]: 96). In the Home Office, the development, coordination and implementation of Prevent is undertaken by the Office of Security and Counterterrorism (OSCT), which also liaises with, and funds, local authorities; cooperates with community groups; commissions research; provides training materials and best practice advise; and evaluates performance ([35]: 111; [42]: 96).

In the OSCT, the Research, Information and Communications Unit coordinates governmental discourse on terrorism, and generates the counter-narrative to challenge extremism. It disseminates it by making 'professional communication skills' available to community groups, by supporting a network of 'credible commentators', and by creating networks that engage schools, universities, and faith organisations. It runs national campaigns and produces a formidable literature (in press, online, and social media), usually under false flags ([37]: 24-25; [42]: 45-49; [15, 16]).

The Home Office's Extremism Analysis Unit gathers extremism intelligence. Its composition and remit are secret for national security reasons. It provides extremism analysis to government departments [46], monitors universities' guest speakers [66], and blacklists groups and individuals to avert extremist infiltration of public sector institutions [86].

While, as a 'key national security issue', Prevent is centrally controlled, it is delivered locally. It engages local authorities that contribute knowledge of, and influence on, local communities. Its local delivery is undertaken by Prevent Panels, comprising top local officials and police chiefs; and their Prevent Partners, which include the whole range of locally delivered public services ([35]: 32-33, 63; [42]: 97). Local authorities ban extremists from using public venues, and filter extremist material from library computers. They distribute Home Office counter-extremism literature, and train their professionals on tackling radicalisation ([45]: 16). Like all public sector institutions involved in Prevent, local authorities vet their (current and prospective) staff to preclude extremist infiltration ([37]: 19).

The key actor at local level is the police. It coordinates all other sectors and provides advice, expertise, and localised risk assessments (Counterterrorism Local Profiles) that inform their tactics. It disrupts extremist activity by intervening in the internet and by 'lawfully disrupting or attending' events involving extremist speakers ([37]: 19-20; 
[42]: 78). It helps devise and deliver de-radicalisation programmes and educate public sector employees on radicalisation; and establishes contacts in neighbourhoods, schools, and homes [55]. Accordingly, police Counter-Terrorism Units have established Prevent Coordinators who advise senior local officials; Prevent Counter-Terrorism Intelligence Officers; and numerous Prevent Engagement Officers who develop local connections and deliver projects ([37]: 6; [42]: 99-100).

In nurseries and schools, the promotion of British values is inspected by Ofsted. Police officers deliver counter-extremism classes; and the Home Office, the Association of Chiefs of Police (ACPO), and the Department for Education (DfE) deliver a variety of materials and events to train students on the dangers of extremism and ways to tackle it ([1, 19]: 7; [42]: 68). Schools recast their curricula to promote 'awareness and patriotism' ([13]: 43-44); and teachers are trained to identify 'vulnerable' pupils and refer them for de-radicalisation. They report any concerns about their pupils' family life; and encourage debate on controversial issues, in order to challenge extremist views and uncover children who 'seek to hide' their extremist propensities ([19]: 5-7; [35]: 66-69; [36]: 10-12; [37]: 26; [45]: 16). Encapsulating the Home Office rationale, schools operationally define extremism as 'the favouring of extreme or fundamental changes in political, economic, or social conditions, institutions, or habits of the mind' ([81]: 30).

The Prevent duty is inserted in the safeguarding section of health staff employment contract ([36]: 13-14). Health professionals are required to diagnose and report signs of radicalisation among their patients and colleagues ([35]: 83-85; [36]: 13-14). Prevent is included in medical students' undergraduate curricula ([35]:84). Radicalisation symptoms are said to include: 'need for identity, meaning, and belonging [...] desire for political or moral change [...] and relevant mental health issues' [77].

Thus, Prevent is delivered by an ad hoc assemblage of public-private and state institutions, which have different missions and operate across different scales of government. It engages a range of actors that are beyond Home Office command and, in panels and partnerships, creates forums with decision-making power. In short, Prevent is a structure of governance ([50]: 228-246, 250-254; [52]: 164-185). Governance assemblages are structured around specific issues and tend to be instrumentalist and managerial. They are not concerned with political or legal principles, but with effectiveness vis-à-vis the goals they set for themselves. Their participants are in $a$ priori agreement regarding the purpose and character of their endeavour, while social actors that could question their aims or approach are excluded ([12]: 115-150; [18]: 59-61; [52]: 175, 178-179).

While inherently exclusionary, governance structures tend to be founded on relations of heterarchy (horizontal self-organisation of mutually interdependent actors) rather than hierarchy; and coordinate their actions through dialogue rather than command ([50]: 228-229; 2016: 167-169). By contrast, Prevent outlines a hierarchical structure. Rather than a network of partners, it comprises graded bodies ('panels'). Its objectives and institutional architecture are determined unilaterally by the central state, and so are the actors involved, their respective roles, and the relations among them. Moreover, the state monitors and evaluates their activities and controls their funding; and it legally compels them to deliver. Thus, in Prevent the networked governance structure is subjugated to a centralised, hierarchical one. Prevent is an organisation of statist governance. 
Through this - diffuse at the bottom, centralised at the top - structure the Home Office mobilises welfare institutions to its effort. Prevent redefines welfare institutions' operations and rationale, and aligns them with those of the security apparatus [73]. Their mission becomes, ultimately, the provision of security; and their specifying relations (doctor-patient; teacher-pupil, etc.) are underpinned by security concerns. This shift in rationale does not come from within the welfare institutions or from their political directorates in the Department for Education or Health; it is imposed by the Home Office. Moreover, while welfare institutions would routinely employ surveillance methods to assist their operations, they are now required to do so in order to serve those of the Home Office. Prevent adjoins welfare institutions to the security apparatus. Whereas, in the context of neoliberal policy, there is a tendency of the security apparatus to capture the social terrain evacuated by retreating welfare institutions [88]; Prevent evidences the capture of welfare institutions as such by the security apparatus.

The institutional architecture of Prevent, which connects the summits of the state to the ground-level of society into a singular, vertical structure under the aegis of the security apparatus, designates Prevent as a state project. State projects are political endeavours generated within the state in order to secure its substantive institutional unity - a unity that is not certain a priory, given the character of the state as a relatively open, emergent, and contradictory system. State projects create the framework within which state agents can coordinate and connect diverse policies. They are typically articulated with a policy paradigm, which informs their orientation ([52]: 84-85). Prevent is a project devised and promoted by three successive governments involving all parties of government. It unifies the state mechanism and mobilises it towards a singular objective. This unification occurs on the basis of security, in a policy paradigm defined by pre-emption, aiming to perpetuate the liberal political present.

\section{Prevent meets the citizen: An hegemonic project}

While Prevent is a state project, it is much more than an internal reconfiguration of the state apparatus. It is addressed to society and depends on it for its delivery. The citizen is both the target and the agent of Prevent. This dual engagement of society is captured in the de-radicalisation process, discussed in this section.

De-radicalisation is undertaken by a Prevent sub-structure, Channel ([44]: 13). Under CtSA duty, local authorities, penitentiary, health, and education institutions establish Channel panels and partnerships. The government stresses that the 'Channel duty' does not confer new functions, but is incorporated in their existing safeguarding responsibilities: radicalisation is said to be akin to other forms of abuse, like domestic violence, sexual exploitation, forced marriage or female genital mutilation ([20,45]: 2, 7, 13). The Channel mission involves identifying individuals vulnerable to radicalisation, and reversing their radicalisation by guiding them to cognitive and behavioural change ([35]: 8; [41]: 3, 7). De-radicalisation comprises three stages: identification and referral of vulnerable individuals; assessment of the risk they run; and drawing and delivering support programmes.

The identification of vulnerable individuals is done by 'frontline' professionals. Social workers, teachers, student support personnel, GPs, nurses and mental health specialists are requested to look out for symptoms of radicalisation among their 
colleagues, students, pupils, and patients. They should be vigilant for expressions that support violence or reject the principle of the rule of law or any elected UK authority; possession of extremist literature and accessing extremist websites; behavioural changes, including withdrawal from family, hostility towards former associates, and association with extremist individuals or groups; and petty criminality, or claims of involvement in organisations that espouse extremism ([35]: 57; [41]: 9-10; [47]:10).

Training in identifying vulnerable individuals is mandatory for all authorities under CtSA duty, and their compliance is monitored by the Home Office ([36]: 14-15). The government provides training through Workshops to Raise Awareness of Prevent (WRAP), which have reached over 800,000 'frontline' staff [48]. The symptoms of vulnerability professionals are trained to look for include: underachievement; rejection by peers or family; witnessing or experiencing hate crime; conflict with family on political, lifestyle, or religious grounds; identity confusion; change in behaviour or appearance; traumatic events (personal, national, or global); poverty, disadvantage; social exclusion; discomfort with one's place in society; alienation from UK values; unemployment; family breakdown; drugs; bullying; exposure to the news or video games; truancy; unhappiness after trip abroad; peer pressure; lack of self-esteem; increased self-worth; desire; fear; concern about global events; autism (HMG [39]: 5-14; also: [1]: 10; [21]: 6; [43, 59]). These symptoms become alarming when they involve a sense of personal or social injustice. They become factors of radicalisation when they combine with the acquisition of an extremist ideology: jihadi, right-wing or left-wing (HMG [39]: 5; [40]: 4; [2]: 42).

Following identification, individuals are referred to the institution's Channel coordinator, are filtered by a Prevent Police Liaison and, those that are found to be genuine cases worthy of attention, are forwarded to the local Channel Panel, which devises a deradicalisation programme tailored to each individual. The programmes are of indeterminate length and may involve any combination of a variety of elements: counselling, employment training, anger management, social networking, mental health treatment, religious tutoring, and citizenship courses ([36]: 21; [41]: 15; [42]: 58-59; [47]: 17-18). Since 2015, Channel referrals have more than doubled, to exceed 6000 in 2017 - an increase attributed to the imposition of statutory duty and to the widening of Prevent targeting [30, 49].

Prevent exceeds the confines of the state to engage ample parts of society: everyone that provides or receives a service in education, health, or social care. It seeks to achieve broad popular participation. Thus, counter-extremism is an hegemonic project. Hegemony refers to a mode of ruling based on moral, intellectual, and political leadership, rather than direct, forceful domination ([28]: 57-58, 181-182; [50]: 6; 2016: 104-107; [83]: 159-241). Hegemonic projects relate the state to the wider society by engaging social support for state endeavours. They link the strategies of the state to appealing visions of the public interest and the good society. They diverge into one-nation and two-nations projects. The former are expansive and inclusive. They aim to mobilise widespread support through symbolic rewards and material concessions (e.g. New Deal, Great Society). Two-nations projects aim to benefit and mobilise some sections of society, while inflicting the costs on others (e.g. apartheid; Thatcherism). They organise support by exploiting (or creating) social cleavages: productive-parasitic, black-white, loyal-disloyal, etc. ([52]: 86-88).

At first glance, Prevent looks like a one-nation project. It seeks to achieve security, a universal good towards which the entire society can mobilise. However, security is an 
exclusionary relation, aimed at the expulsion and neutralisation of the suspect person, group, behaviour, or thought ([63]: 11-12). Characteristically, the former Prime Minister declared that it is 'not simply enough to target and go after violent extremists after they have become violent. We have to drain the swamp which they inhabit' (Cameron, in [89]). Prevent is marked by persecutory zeal that is not contained to present conditions but pre-emptively spills over to the future. It seeks not only to neutralise the enemy, but to deny the conditions for his existence. The enemy is the extremist, defined as the anti-liberal. Thus, Prevent is a two-nations project, defined in political terms. It is premised on, and promotes, the cleavage between the liberal citizen and the non-liberal anti-citizen.

Hegemony is a mode of rule based on leadership, on movement towards. Hegemony is future-oriented, a sense captured in the term hegemonic project. Indeed, such projects always constituted mobilisation towards some kind of social change, towards a future. Here lies another paradox: in seeking to neutralise the potential for political change, counter-extremism is an hegemonic project aiming to impose social stasis.

Crucial to the hegemonic appeal of Prevent is the terms on which it mobilises society. It seeks to engage welfare professionals not in coercion, but in care, merely expanding the duty of care inherent in their professional ethos. Indeed, they respond positively to their 'safeguarding' duty - the latter makes Prevent tasks easier to perform and dissolves their suspicion and resistance towards the project, precisely because it matches their professional ethos ([13]: 23-24, 32-34, 61; [33]: 2). Motivating Prevent delivery is a logic of care: an open-form, embodied logic, aiming to provide wellbeing [29, 61]. This care reaches the individual as therapy: through intervention in, and management of, the development of emotions, cognition, and worldviews. Care is not only instrumental for the hegemonic appeal of Prevent. It defines the modality of power the state exercises through counter-extremism, and is the mould in which it forges political subjectivities. The following section discusses these issues.

\section{Pastoral tyranny, suspicious subjects}

The power Prevent exercises is directed to vulnerable individuals and seeks to save them from extremism through guidance, not force. De-radicalisation describes a power based on the vigilance of welfare professionals and the confession of vulnerable individuals. It is delivered through mentoring and therapy programmes, and aims to redeem the vulnerable person by re-introducing her to society as a liberal citizen ([25]: 169-180). This pastoral power cares for its subjects, individually and collectively, safeguards them from danger, and heals the injured ones. It is manifested not as a display of might or grandeur, but as a duty: 'zeal, devotion, and endless application'. It is based on the extraction of its subjects innermost truth; and its application is total: it conducts, leads, guides, and urges its subjects at every instance, throughout their life ([27]: 126-128, $165,182-185)$. Its foundational premise is that every individual requires protection from her own inclinations and impulses ([8]: 61). The ultimate aim of this caring power is to save the individual from the threat she represents to herself.

Pastoral power is alien to any modern relation between state and society, and obviously anti-liberal. Liberalism is founded on the imaginary of a rational, 
autonomous and creative individual, naturally endowed with freedom. The state cannot legitimately infringe this innate freedom, hence its powers are limited. Crucially, the state cannot transgress the inner space of the individual to extract its hidden truth: the liberal individual - and society - remain opaque vis-à-vis the state [79]. But if power is founded on the imaginary of the vulnerable individual that needs saving from herself, then state intervention is justified, including in her formation of emotions and ideas. Interestingly, while recognising pastoral power as an affront, liberalism sees it as a 'legitimate mode of government in dealing with the barbarians, provided the end be their improvement and the means justified by actually effecting that end' ([60]: 13). In this sense, Prevent can be seen as a colonial 'civilising' project - only this time the colony is British society.

As state power is a social relation, and a strategic intervention in the social realm, the advent of pastoral power through counter-extremism implicates social relations. Indeed, Prevent intervenes in social relations (between teacher and student, doctor and patient, sacerdote and faithful, social worker and social care recipient, parent and child), to recast and homogenise them as relations of security. It installs security as the social master-relation, the relation that determines all others. This, in turn, makes policing ubiquitous, involving everyone as subject and as object. This threatens to destroy the relations of trust, the social bonds and affinities that are necessary for society. Foucault noted that pastoral is an individualising power, directed towards all and each, but not towards the higher unity that they form ([27]: 128-129). Prevent indicates that this is so because its subjects do not form any 'higher unity'; they are a 'population', not a 'society'. This completes the hegemonic paradox of counter-extremism: a project of social mobilisation whose success entails the dissolution of society. Aristotle already knew that the dissolution of trust - of society - is the condition for, and ultimate achievement of, tyranny. 'Eliminate trust and put every slave under the surveillance of the other slaves' ([5]; [78]: 20-21). The society of Prevent is a colony of mutually policing individuals whose relations are defined and mediated by the security apparatus of an authoritarian state.

The defining subjectivity of this society, and object of Prevent's pastoral care, is the vulnerable individual. The endless symptomatology of vulnerability implies that vulnerability is a universal condition, a dogma promulgated in Prevent guidelines and training materials ([33]: 5, 10-12, 19). The inculcation of vulnerability instils a diminished sense of the self and its abilities, and denies it autonomy and emancipatory potential. It turns the citizen from a creative, responsible subjectivity to an endangered one, dependent on state protection. It thus necessitates and legitimises the use of state force for protective purposes. The vulnerable individual is an anti-democratic construal, pertaining to authoritarian political relations ([24]: 11-12; [65, 74]).

The vulnerable individual is not only threatened, but also threatening. Vulnerability means promptness to dangerousness. The vulnerable individual is already conceptualised as dangerous ([31]: 408). She attracts care only insofar as she triggers suspicion. Prevent's therapeutic approach is the method of a security strategy; the logic of care is informed by that of security. This is a closed logic, intolerant to questioning, dialogue or critique. 'One accepts the imperative principle of security in order to become obedient and one reproduces this state of obedience in a striving for the mythical state of security. The ultimate goal is that people should be dissuaded from 
opposing the security of the thing which they are told provides them their own security' ([63]: 8-9). What Prevent strives to protect is not the vulnerable individual, but the liberal social order this individual may come to threaten.

Finally, while the construct of the vulnerable individual and its placement at the heart of power relations redefines political organisation and culture, the construct itself is suspended. The vulnerable individual is unformed: it will fall on either side of Prevent's hegemonic cleavage: it will become a liberal citizen or a radical anti-citizen. Through its indeterminacy, the vulnerable subject demarcates two conflicting political subjectivities that strive to determine it. One is the liberal citizen: the caring professional, versed in the ways of the threat, and seeking to safeguard the vulnerable individual from extremism, to make it like her. She is an active citizen; but her active-ness is instructed by the state. She is mobilised to perform within a state-defined normative, operational, and cognitive framework. She is an activated citizen, charged with responsibilities but without control over the context, meaning, and effects of her actions ([9]: 130-131; [87]: 423-425). She is, effectively, a security agent, trained and directed to discover signals of threatening potentiality in those she comes in contact with. While focused on the formation of deviant political worldviews, these signals may reside in virtually anything. Thus, for the Prevent agent suspicion constitutes the undercurrent of social relations, a hypodermic social bond. On the other side of the vulnerable individual is the extremist, the un-British anti-citizen. Her purpose is also to cast the vulnerable subject to her image - to lure them into extremism. These two opposing subjectivities are united by a bond: suspicion. The security citizen suspects her fellow citizens of (propensity to) radicalism. The extremist suspects her fellow citizens of suspecting her. The two opposing subjectivities are synthesised into a subject that universally suspects and is suspected. As Prevent undermines the trust necessary for society, it creates the subjectivity that will populate and reproduce the security colony: the suspicious citizen.

\section{Conclusion: Prevent, an extremist project}

Counter-extremism is a state strategy aiming to prevent the formation of nonliberal subjectivities, and hence cancel the possibility of a non-liberal political future. It divides society along an irreconcilable liberal/non-liberal cleavage, and brings a unified state mechanism to police the relation between the individual and her mind. Its constitutive paradox is obvious: counter-extremism destroys liberalism by protecting it.

Prevent contravenes each of the liberal/British values it specifies, starting with the rule of law. While CtSA imposes a statutory duty upon public sector institutions, it does not define this duty and the obligations it entails, as is required by rule of law principles ([76]: 61-64), but lets the Home Secretary to determine them unilaterally, in piecemeal fashion. Similarly, none of the aspects of Prevent (the roles of different agents, the quality of educative materials, the referral and treatment of individuals) is regulated by law or overseen by anyone outside the Home Office [4]. Incredibly for a liberal polity, this unregulated apparatus infringes the autonomy of individuals that are not suspected of anything unlawful 
([33]: 5). Considering the range of social relations that Prevent implicates, this signals a decline of law as regulator of state-society relations. The 'muscular liberalism' of counter-extremism overwhelms legality: 'A passively tolerant society says to its citizens, as long as you obey the law we will leave you alone [...] But I believe a genuinely liberal country does much more; it believes in certain values and actively promotes them' [14]. Thus, counter-extremism tends to lift the distinction between law and morality; it does so in order to cancel the freedom of conscience - the archetypical seat of human rights ([7]: 230-232).

Accordingly, Prevent persecutes people who, by Home Office admission, have done nothing illegal ([42]: 99). Regardless, the Government declares that '[t]here should be no ungoverned spaces' in which 'extremism is allowed to flourish' ([42]: 8-9); and proclaims to 'drain the swamp', showing Prevent as a project premised on the existential friend/enemy distinction that, moreover, dehumanises the enemy ([80]: 54). The enemy is whoever espouses 'ideologies that state that violence is an acceptable course of action' ([42]: 44). Yet, all ideologies, including liberalism, contemplate violence in certain circumstances. Designating 'violent ideologies' as antithetical to liberalism justifies persecution on ideological grounds.

Regarding freedom of speech, counter-extremism targets the formation, expression, and circulation of political ideas, to repress the development of convictions that antagonise liberalism. The emphasis on repressing political ideas is scandalous for a liberal-democratic state. It raises a further paradox: while liberal-democratic institutions function perfectly, the condition for democratic politics, the free formation of opinion, is circumscribed.

By circumventing the rule of law and suppressing political ideas, Prevent is problematic vis-à-vis democracy. Furthermore, it unifies the state mechanism under the aegis of the security apparatus, and intervenes in individuals' cognitive formation. Crucially, it does so in order to prevent non-liberal subjectivities from forming. In this manner it seeks to pre-empt the future, and fix society in a perpetually reproduced liberal present. Each of these features is anomalous in a liberal democracy; their combination in a singular project designates it as authoritarian.

In inculcating its subjects as 'vulnerable', the state reduces them to objects of its power. Deprived of capacity for autonomous, meaningful agency, they are a negation of the modern subjectivity of the citizen as a co-creator of society and history [81]. They populate a society of generalised suspicion, with severed bonds of trust, colonised by the intolerant logic and paranoid mindset of security. Thus, Prevent contravenes the liberal values it sets out to protect; it is premised on authoritarian perceptions of society, power and subjectivity. It is a deeply anti-liberal and therefore, in its own terms, an extremist project.

The state seeks to combat extremism through an extremist project; it devices a governance mechanism that is statist; it mobilises society in a hegemonic project that negates hegemony and society. The paradoxes cut to the core of the counter-extremism state. It seeks to fix society in an eternal political present because it cannot offer a vision for the future. It conscripts society in security programmes because it cannot mobilise it in a project of progress, freedom or welfare. It conceptualises political change ('extremism') as a threat, because it is insecure; it is suspicious of society because it is unstable. The authoritarian 
state is brittle [67]. Unable and unwilling to change, it faces the future as a threat. The vulnerable subject at the heart of the counter-extremism ideology is, in fact, the state.

Acknowledgments The author wishes to thank Fatima Ahdash (LSE); Val Aston (East Anglia); Bob Brecher (and everyone at the Brighton Centre for Applied Philosophy, Politics and Ethics); Anwen Ebenezer (Cardiff); and Ervjola Selenica (Trento) for their critical and encouraging comments on earlier drafts of this paper.

Open Access This article is distributed under the terms of the Creative Commons Attribution 4.0 International License (http://creativecommons.org/licenses/by/4.0/), which permits unrestricted use, distribution, and reproduction in any medium, provided you give appropriate credit to the original author(s) and the source, provide a link to the Creative Commons license, and indicate if changes were made.

\section{References}

1. ACPO (2013) 'Prevent, Police and Schools'.

2. ACPO (Association of Chief Police Officers) (2012) 'Prevent, Police and Universities'.

3. Ali, N. (2015). Mapping the Muslim community: The Politics of counter-radicalisation in Britain. In C. Baker-Beall, C. Heather-Kelly, \& L. Jarvis (Eds.), Counter-radicalisation: Critical perspectives. Abington: Routledge.

4. Anderson, D. QC (2016) 'Supplementary Written Evidence Submitted by David Anderson QC, Independent Reviewer of Terrorism Legislation' Home Affairs Select Committee, 29 January. http://data.parliament.uk/writtenevidence/committeeevidence.svc/evidencedocument/home-affairscommittee/countering-extremism/written/27920.pdf

5. Aristotle, Politics, V, 11.

6. Blackburn, J., \& Walker, C. (2016). Interdiction and indoctrination: The counter-terrorism and security act 2015. The Modern Law Review, 79(5), 840-870.

7. Bloch, E. (1987). Natural law and human dignity. Cambridge: MIT Press.

8. Bobbio, N. (1990). Liberalism and democracy. London: Verso.

9. Boukalas, C. (2012). US citizen corps: Pastoral citizenship and authoritarian Statism. Situations, 2(4), $117-140$

10. Boukalas, C. (2014). Homeland security, its law, and its state. Abington: Routledge.

11. Brooks, R. M., \& Holford, A. K. (2009). Citizenship, learning and education: Themes and issues. Citizenship Studies, 13(2), 85-103.

12. Brown, W. (2015). Undoing the demos. New York: Zone.

13. Busher, J et al (2017) 'What the prevent duty means for schools and colleges in England'. Aziz Foundation.

14. Cameron, D. (2011) 'PM's speech at Munich security conference' Cabinet Office, 5 February.

15. Cobain, I., Ross, A., Evans, R. and Mahmood, M. (2016a) 'Inside RICU, the Shadowy Propaganda Unit Inspired by the Cold War' The Guardian, 2 May.

16. Cobain, I., Ross, A., Evans, R. and Mahmood, M. (2016b) 'UK's covert propaganda bid to stop Muslims joining Isis' The Guardian, 2 May.

17. Coppock, V., \& McGovern, M. (2014). Dangerous minds? Deconstructing counter-terrorism discourse, radicalisation and the 'psychological vulnerability' of Muslim children and young people in Britain. Children and Society, 28, 242-256.

18. Davies, J. (2011). Challenging governance theory. Bristol: Policy.

19. Department for Education (2015a) 'The Prevent Duty - Departmental Advice for Schools and Childcare Providers' (DFE-00174-2015).

20. Department for Education (2015b) 'Keeping Children Safe in Education' (DFE-00129-2015).

21. Department of Health (2011) 'Building partnerships, Staying Safe - the Health Sector Contribution to HM Government's Prevent Strategy: Guidance for Healthcare Workers.

22. Dodd, V. (2016) 'Police study links radicalisation to mental health problems'. The Guardian, 20 May.

23. Eagleton, T. (1999). Local and global. In B. Circle (Ed.), The Politics of human rights. London: Verso. 
24. Ecclestone, K., \& Hayes, D. (2009). The dangerous rise of therapeutic education. Abington: Routledge.

25. Elshimi, M. S. (2017). De-radicalisation in the UK prevent strategy. Abington: Routledge.

26. Everson, M. (2003). Subjects or citizens of Erewhon? Law and non-law in the development of British citizenship. Citizenship Studies, 7(1), 57-84.

27. Foucault, M. (2007). Security, territory, population. Basingstoke: Palgrave Macmillan.

28. Gramsci, A. (1998). Selections from the prison notebooks. London: Lawrence and Wishart.

29. Groves, C. (2017). Care, uncertainty and intergenerational ethics. Basingstoke: Palgrave Macmillan.

30. Halliday, J. (2016) 'Almost 4,000 People Referred to UK Deradicalisation Scheme Last Year' The Guardian, 20 March.

31. Heath-Kelly, C. (2013). Counter-terrorism and the counterfactual: Producing the 'radicalisation' Discourse and the UK Prevent Strategy. The British Journal of Politics and International Relations, $15,394-415$.

32. Heath-Kelly, C. (2017). The geography of pre-criminal space: Epidemiological imaginations of radicalisation risk in the UK prevent strategy 2007-2017. Critical Studies on Terrorism, 10(2), 297-319.

33. Heath-Kelly, C., \& Strausz, E. (2018). The banality of counterterrorism “after, after 9/11"? Perspectives on the Prevent Duty from the UK Health Sector. Critical Studies on Terrorism. https://doi.org/10.1080 /17539153.2018.1494123.

34. Heath-Kelly, C., Baker Beall, C., \& Jarvis, L. (2015). Introduction. In C. Baker-Beall, C. Heath-Kelly, \& L. Jarvis (Eds.), Counter-Radicalisation. Abington: Routledge.

35. HM Government (2011) 'Prevent Strategy' (Cm 8092).

36. HM Government (2015a) 'Revised Prevent Duty Guidance for England and Wales'.

37. HM Government (2015b) 'Counter-Extremism Strategy' Cm9145.

38. HM Government (2018) 'CONTEST. The United Kingdom's Strategy for Countering Extremism'. Cm9608.

39. HM Government (n.d.) 'Facilitator's Workbook' Workshop to Raise Awareness of Prevent.

40. HM Government (n.d.) 'Full Workshop Script' Workshop to Raise Awareness of Prevent.

41. Home Office (2010) 'Channel: Supporting Individuals Vulnerable to Recruitment by Violent Extremists' (HO_01490_G).

42. Home Office (2011) 'CONTEST. The United Kingdom’s Strategy for Countering Terrorism', Cm8123.

43. Home Office (2012) 'Channel: Vulnerability Assessment Framework'.

44. Home Office (2014) 'CONTEST. The United Kingdom's Strategy for Countering Terrorism - Annual Report' Cm8848.

45. Home Office (2015a) 'CONTEST. The United Kingdom's Strategy for Countering Terrorism - Annual Report', Cm9048.

46. Home Office (2015b) FOI Ref: 34830 (22 April).

47. Home Office (2015c) 'Channel Duty Guidance'.

48. Home Office (2017) 'Fact Sheet: Prevent Strategy'.

49. Home Office (2018) 'New Figures Show Improved Referrals to Prevent and Rise in Far-Right Concerns'. Press Release, 27 March.

50. Jessop, B. (2002). The future of the capitalist state. Cambridge: Polity.

51. Jessop, B. (2008). State power: A strategic-relational approach. Cambridge: Polity.

52. Jessop, B. (2016). The state: Past, present, future. Cambridge: Polity.

53. Krasmann. (2007). The enemy on the border - Critique of a Programme in favour of a preventive state. Punishment and Society, 9(3), 301-318.

54. Kundnani, A. (2015). Radicalisation: The journey of a concept. In C. Baker-Beall, C. Heather-Kelly, \& L. Jarvis (Eds.), Counter-radicalisation: Critical perspectives. Abington: Routledge.

55. Lamb, J. (2012). Preventing violent extremism; a policing case study of the west midlands. Policing, 7(1), 88-95.

56. Martin, T. (2015). Challenging the separation of counter-terrorism and community cohesion in prevent. In C. Baker-Beall, C. Heath-Kelly, \& L. Jarvis (Eds.), Counter-Radicalisation. Abington: Routledge.

57. Marx, K. (1936 [1847]). The poverty of philosophy. London: M. Lawrence.

58. May, T. (2017, 4 June) 'PM statement following London terror attack'. London: Prime Minister's Office.

59. MET (Metropolitan Police Service) and College of Policing (n.d.). 'Channel General Awareness Training'.

60. Mill, J. S. (2015). On liberty, utilitarianism and other essays. Oxford: OUP.

61. Mol, A. (2008). The logic of care. Abington: Routledge.

62. Neocleous, M. (2016). The universal adversary. Abington: Routledge.

63. Neocleous, M. (2017) 'Qu'est-ce qui git dans la Boue?' In: De Simoni, Guillibert and Krickeberg (eds) Critique de la Sécurité: Pacification et Accumulation. Paris: Eterotopia. 
64. O’Donnell, A. (2017). Pedagogical injustice and counter-terrorist education. Education, Citizenship and Social Justice, 12(2), 177-193.

65. O'Donnell, A. (2018). Contagious ideas: Vulnerability, epistemic injustice and counter-terrorism in education. Educational Philosophy and Theory, 50(10), 981-997.

66. PM Office (2013) 'PM's Extremism Taskforce: Tackling Extremism in Universities and Colleges Top of Agenda' (17 September).

67. Poulantzas, N. (1976). The crisis of dictatorships. London: NLB.

68. Poulantzas, N. (1978). State, power, socialism. London: Verso.

69. Powell, L. (2016). Counter-productive counter-terrorism. How is the dysfunctional discourse of prevent failing to restrain radicalisation? Journal for Deradicalisation, 8, 46-99.

70. Press Association (2013) 'David Cameron launches anti-terror task force to tackle extremism', 26 May.

71. Ragazzi, F. (2016). 'Suspect community or suspect category? The impact of counter-terrorism as 'policed multiculturalism. Journal of Ethnic and Migration Studies, 42(5), 724-741.

72. Ragazzi, F. (2017a) 'Students as suspects?'. Council of Europe (https://www.book.coe.int).

73. Ragazzi, F. (2017b). Countering terrorism and radicalisation: Securitising social policy? Critical Social Policy, 37(2), 163-179.

74. Ramsay, P. (2009). The theory of vulnerable autonomy and the legitimacy of civil preventative orders. In B. McSherry, A. Norrie, \& S. Bronitt (Eds.), Regulating deviance. Oxford: Hart.

75. Richards, A. (2011). The problem with 'radicalisation': The remit of 'prevent' and the need to refocus on terrorism in the UK. International Affairs, 87(1), 143-152.

76. Roxin, C. (2000). Politica Criminal y Sistema del Derecho Penal. Buenos Aires: Hammurabi.

77. SACC (Scotland Against Criminalising Communities) (2015) 'NUS Votes to Oppose Prevent' (24 April).

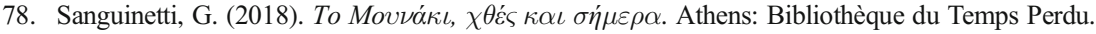

79. Scheuerman, W. E. (2016). Digital disobedience and the law. New Political Science, 38(3), 299-314.

80. Schmitt, C. (1996). The concept of the political. Chicago: UCP.

81. Sukarieh, M., \& Tannock, S. (2015). The Deradicalisation of education: Terror, youth, and the assault on learning. Race and Class, 57(4), 22-38.

82. Taylor, J. (2018). Suspect categories', Alienation and Counterterrorism: Critically Assessing Prevent in the UK. Terrorism and Political Violence. https://doi.org/10.1080/09546553.2017.1415889.

83. Thomas, P. D. (2010). The Gramscian moment. Chicago: Haymarket.

84. Thomas, P. (2015). Prevent and community cohesion in Britain: The worst of all possible worlds? In C. Baker-Beall, C. Heather-Kelly, \& L. Jarvis (Eds.), Counter-radicalisation: Critical perspectives. Abington: Routledge.

85. Thomas, P., \& Sanderson, P. (2011). Unwilling citizens? Muslim young people and National Identity. Sociology, 45(6), 1028-1144.

86. Travis, A. (2015) 'Home Office to blacklist extremists to protect public sector' The Guardian, 23 March.

87. van der Land, M. (2014). Citizens policing citizens: Are citizens' watches manifestations of contemporary responsible citizenship? Citizenship Studies, 18(3-4), 423-434.

88. Wacquant, L. (2009). Punishing the poor. Durham: Duke UP.

89. Wintour, P. (2013) 'Cameron vows to 'drain the swamp' creating Islamic extremism' The Guardian, 3 June.

Publisher's note Springer Nature remains neutral with regard to jurisdictional claims in published maps and institutional affiliations. 